\title{
EARLY MARRIAGE: NEGLECTED FORM OF CHILD ABUSE
}

\author{
Rachana C. Raval, Dr. Bhavesh H. Bharad
}

\author{
Ph.D. Research Scholar, \\ University School of Law, \\ Gujarat University, Ahmedabad. \\ rachanacraval@yahoo.com \\ Assistant Professor \\ University School of Law, \\ Gujarat University, Ahmedabad. \\ dr.bharad@gujaratuniversity.ac.in
}

\begin{abstract}
The practice of "Early Marriage" has been an ancient phenomenon specially developed for girl's arranged marriage in the disguise of "Paro" (which means a bride bought from other regions i.e., transnational migration) or "Molki" (Paid brides in which girl's family gets money from groom's family). The impoverishment is the pushfactor behind bride trafficking in Northern Lines of India. Female feticide and infanticide have declined the sex ration and has resulted in shortage of brides. The "Molki" practice is more prevalent among backward class because disadvantaged class are poverty stricken social groups which are unable to find local brides in their own community; as a result, the social group opts for paid bride from other regions which gradually makes a practice among community. These men resort to buying inter-region brides from the poorer areas. Early marriage of child benefits both the families by rendering money to the poor family and bride to the disadvantaged family against monetary exchange. North-East states are more affected by inter and intra trafficking of brides against monetary transaction. As such trafficking includes forced sale or resale minor girls in the fake name of marriage, sometimes girls are abducted, raped or abused for sexual slavery and marriage at the clemency of the groom and his family who have "paid" for her. Dearth, orphan at early childhood age, lack of education, orthodox and culturally sanctioned harsh practices and norms, monetary quest of parents, parental separation, etc. are major push factors contributing in the rise in bride trafficking.

The practice is profoundly more in rural and tribal areas because bride prices are much higher among rural communities. In counterfactual exercises, parents entirely rely on early marriage and bride price for their easy survival. Taking into consideration the positive side of bride trafficking, lack of steady economic market cannot fill the financial gap of poor families and unnecessary prohibition upon such reciprocal practices may worsen the life of daughter's parents.

"The society in which a girl child is accepted unwillingly and in the form of burden, bride trafficking is an absurd reality for such society." ITPA (Immoral Trafficking Prevention Act) is the special statute enforced to curb illegal activities like forced prostitution, sexual abuse, and minor's trafficking but the act is insufficient to cover all he forms of crimes and trafficking. Thus, this article involves analyses of current situations, demographic data, various aspects of bride trafficking, causes and current legal status on bride trafficking. In first section, the paper will explain technical definition of every term related to early marriage given by institutions like United Nations and special departments. In second section, the affecting factors accountable for trafficking of minor brides through forced marriage will be discussed at length. In last part, the impact upon the society along with statistic data will be narrated. Consequently, the paper will focus on transforming stage of issue of bride-trafficking which earlier existed in hidden form but now a days has become culturally sanctioned practice in society.
\end{abstract}

Keywords: Early marriage, Child Trafficking for Marriage, Female Feticide, Poverty

\section{INTRODUCTION:}

"Human trafficking, as a social evil, exists in human societies for ages. It has become a global problem and affecting people of all castes, classes, ages and gender, in fact, it is the new form of slavery" (UNODC, 2013). According to Global Report on Trafficking in Persons "the term 'modern slavery' has recently been used in various context such as practice of trafficking in persons, forced labour, slavery, but also for child labour, forced marriages and others". The Global Slavery Index (2016) estimated that 45.8 million people are trapped in some form of modern-day slavery across 167 nations globally; nearly 18.35 million people are estimated to be residing in India. 


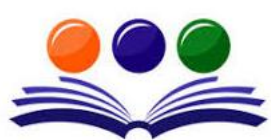

GRAND ACADEMIC PORTAL RESEARCH JOURNALS

A GLOBAL JOURNAL OF SOCIAL SCIENCES

( ISSN - 2581-5830 )

Impact Factor - SJIF - 4.998, IIFS - 4.375

Globally peer-reviewed and open access journal.

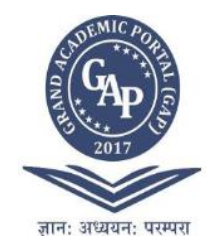

Similarly, to other consumer products, India also has a huge market for sex trade as one of the world's most populated countries. Illiteracy, poverty, political corruption, patriarchy, and a lack of awareness are all factors that encourage human trafficking for sex trade in India. As mentioned by "The Protection Project Report", India has been the country of source, transport and destination area for human trafficking. Almost 90 percent of human trafficking in India is intra-state and mostly targets national markets. The vast majority of trafficked Indians are sold into Middle Eastern countries for sex work, forced marriages, and forced labor. Human trafficking is one of the most prevalent activities in India, where gender disparities and issues of gender equality are not given enough attention.

\section{EARLY MARRIAGE - THE CONCEPT:}

The 'Palermo Protocol' of United Nations, also known as 'The protocol to prevent, suppress and punish trafficking in persons' (2000), provided the most acceptable and broad definition of human trafficking. Article 3, paragraph (a) of this protocol defined human trafficking as "Trafficking in Persons shall mean the recruitment, transportation, transfer, harboring or receipt of persons, by means of the threat or use of force or other forms of coercion, of abduction, of fraud, of deception, of the abuse of power or of a position of vulnerability or of the giving or receiving of payments or benefits to achieve the consent of a person having control over another person, for the purpose of exploitation. Exploitation shall include, at a minimum, the exploitation of the prostitution of others or other forms of sexual exploitation, forced labor or services, slavery or practices similar to slavery, servitude or the removal of organs".

A trafficking act is clearly defined by its purpose, means of recruitment, and methods of exploitation. Besides, the UN definition, trafficking of human is defined as someone who trades something that should not be traded based on various social, economic, or political reasons. Researches use terms like drug trafficking, arms trafficking, and human trafficking to delineate from the larger paradigm of trafficking. Human trafficking is often associated with exploitation of children and women. Bridal trafficking is the illegal transfer of women and girls for the purpose of marriage by force, false promises or deception as part of the broad concept of human trafficking.

It has been reported from time to time that women and girls are trafficked for marriage in the past, but now the trafficking is widespread, organized, and carried out on a large scale. Forced marriage is common in southeastern parts of Asia where consent of victims or women is not obtained. False promises of marriage and employment lure the women and girls from their native lands.

Several Indian states have been impacted by human trafficking, where women are forced into marriages and then sold from one hand to another. The issue of revictimization is also rampant in Northern parts. It appears that a marriage is taking place, but there is a specific purpose for it, such as the employment of a male child or the exploitation of sexual energy. After the purpose served, the minors are sold at any price to another person. This practice is prevalent throughout Haryana, Punjab, Rajasthan and Uttar Pradesh. The Mewad Province spread in three states namely Haryana, Rajasthan and Uttar Pradesh, is the main destination area of bride trafficking in India. Victims of bride trafficking in northern India are named as "Paros" and "Molki".

\section{LEADING FACTORS OF EARLY MARRIAGE:}

The advent of sex determination via ultrasound has resulted in a significant gender disparity, as well as a dearth of suitable brides, in certain areas of India, despite the legality of sex-selective termination. The subsequent demand for brides, particularly in rural communities where many girls of marriageable age have migrated to cities for employment, has fuelled the trafficking of women for forced marriage. he resulting demand for brides is fueling women's trafficking for forced marriage, especially in rural areas where many marriable girls have moved to cities for employment. In some cases, the girl was forced to marry and was subsequently reported to be used as an unpaid worker. Biased proportions are not the only reason for brides' transactions, but there are several other reasons for this practice, such as poverty, dowry, caste and gotra systems and illiteracy. The main causes and reasons for early marriage are as under:

\section{DECLINING SEX RATIO AND SEX-SELECTIVE APPROACH:}

According to a study by the United Nations Office on Drugs and Crime, biased gender ratios in northern India are similar to those in Haryana, Punjab, Rajasthan and western Uttar Pradesh. Other states have accused them of giving birth to girls that are forcefully involved in mass trafficking, forced marriages and forced labour. It is impossible to find a bride for all men because the gender ratio is uneven as women per 1,000 men in Punjab (895), Haryana (879), Uttar Pradesh (912); the only solution is to import bride for left grooms. In such states, the demographic situation is so skewed that it will take years for the situation to stabilize. The demand for girls of marriageable age was so high that organized blackmail began to take place in Haryana, Punjab and Uttar Pradesh. Trafficking in forced marriages has also been reported from the Saurashtra-Kutch province of Gujarat. Lots of Bengali-speaking women are being trafficked from West Bengal and Bangladesh to Kutch, where they 


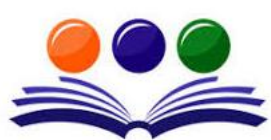

GRAND ACADEMIC PORTAL RESEARCH JOURNALS

A GLOBAL JOURNAL OF SOCIAL SCIENCES

( ISSN - 2581-5830 )

Impact Factor - SJIF - 4.998, IIFS - 4.375

Globally peer-reviewed and open access journal.

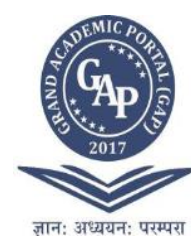

are sold off as brides due to the skewed sex ratio of the region and the desperate search of wives by unmarried men. A significant number of these women are also coerced into the trade of sex.

Sex selection and frequent abortion are significant factors in the exploitation of women for forced marriages in Haryana and Punjab. Haryana is famous for the sex-selective abortion in poverty driven regions. Patriarchy, gender discrimination and low status of women in the society provide a suitable environment for female feticide in many states. The trafficking of women and girls, mainly from eastern and north-eastern states to Haryana, Punjab and Uttar Pradesh, is also a result of the mass genocide in these states.

\section{DOWRY DEMAND AND IMPOVERISHMENT:}

Dowry and poverty are also responsible for the trafficking of brides at both origin and destination. Dowry has been a major driver of bridal trafficking in areas such as Haryana, Punjab, and western Uttar Pradesh where there are dowry systems associated with marriage. It is very difficult to find a bride because some people cannot afford all the expenses associated with a wedding. In this case, they buy the bride through a trafficker and take her to Haryana and Punjab. They have to pay a certain amount to buy the bride, which is not a huge amount. Buyers are relieved that they do not have to spend money on other traditional ceremonies important to their wedding.

Poverty and dowry are very closely linked to the bridal trade. Almost all source regions are very poor and dowry is very common in these regions. Parents cannot find local fiancées in some areas of Bihar, Jharkhand and West Bengal due to the high demand for dowry. In some cases, the bride's parents are very poor and cannot afford the dowry. So, marrying your daughter to a stranger is your only option, as strangers don't need a dowry. For certain cases simply, all marriage expenses are borne by the procurer or groom. In this situation, the groom gives the money to the bride's parents to get their daughter married. So, these kinds of areas are the hot spots of bride trafficking, as the traffickers find it very easy to traffic girls from such areas. The main reasons for trafficking in Assam and Bihar are poverty, unemployment, migration from rural to urban areas, armed conflict, communal conflicts, natural disasters, etc. There is a trend to send children to other states for education, which sometimes ends in the exploitation of children.

\section{LESS EFFICACY OF EXISTING LAWS AND LACK OF LEGAL LITERACY:}

The National Human Right Commission (NHRC) Action Research Report claimed that there is a very low level of awareness and sensitization about the crime of human trafficking among the people of source areas and law enforcement agencies and this continued to be a low priority area. The results exhibited by the study exhibited that there is constant rise in the numbers of missing child and woman. The Ministry of Home Affairs (MHA) realized the severity of trafficking of children that preyed on human suffering and stated that it contravenes the civil and fundamental rights of individuals guaranteed by the Government. The issue is not emphasized much by mainstream media and existing authorities. High profile cases and public pressurized matters are sometimes reported in newspapers.

Various NGOs are working on various issues, and some of them are also focusing on child abuse within areas of source and destination areas. However, there is limited intervention by non-governmental organizations and Government institutions. Some organizations in North India are battling the evils of trafficking in brides, such as Empower People and Shakti Vahini.

\section{EARLY MARRIAGE AND ITS CONSEQUENCES:}

The victims of early marriage and forced trafficking faced several problems. First, they are used as bonded labor in agricultural fields and animal husbandry and later on they are sold to brothels or hotels. The issue of re-victimization is like a cycle in the life of a victim. The buyer exploit the minor sexually and physically. They are often sexually exploited in many cases by other members of the family. The main problems experienced by the victims are as follow:

\section{FORCED PROSTITUTION AND CHILD LABOUR:}

Often considered as consented marriage, every year, thousands of young women and girls are lured into the fake promise of a happy married life with a rich man in Haryana and Punjab. One thing that is very similar to trafficking of minor brides and child prostitution is that both victims are sexually and physically abused. In some cases, the victims of early marriage are used as "sex slaves" and male members of the buyer's family have access to sexual exploitation. Corporal punishment to the victims was most frequent when they resist against buyers. After a certain period of time, the victims are sold to another person and the same exploitation cycle is repeated.

Most purchased brides are exploited sexually, with least basic fundamental rights, used as maids or laborers, and eventually abandoned or sold to another person. Northern states have recorded the lowest sex ration in 


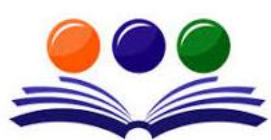

GRAND ACADEMIC PORTAL RESEARCH JOURNALS

A GLOBAL JOURNAL OF SOCIAL SCIENCES

( ISSN - 2581-5830 )

Impact Factor - SJIF - 4.998, IIFS - 4.375

Globally peer-reviewed and open access journal.

the country. These areas are also the agriculturally rich and have a high demand for agricultural laborers. The victims of early marriage are also used as bonded labor and perform both agricultural work and household chores.

\section{BUYING AND SELLING OF "PARO":}

Social activists and NGOs fighting against early marriage and forced prostitution in India, conducted a study in the Mewad District of Haryana and found that 79 percent of "Paro" girls in Mewad were Muslim, 70 percent were belonging to Scheduled Tribes (ST) and 4 percent were Dalits. Fifty-seven percent of them were sold twice, twenty-four percent thrice and six percent more than three times. Most of the victims did not have a right of participation in family matters, seventy-two percent did not participate in functions or festivals. Eightyone percent women said that their names were not there in the ration card or voters list.

\section{HEALTH ISSUES AND LACK OF ACCESS TO HEALTH SERVICES:}

In addition to being a criminal and human rights problem, bride trafficking has serious implications for public health. Victims of child marriage also suffer from violence resulting in physical, sexual and emotional abuse. Health threats and outcomes include sexually transmitted infections, premature pregnancy, forced abortion and abortion-related complications, rape and other bodily attacks.

\section{LOCALITY AND ETHNIC CLASH:}

According to Rahman (2009), the victims of child marriage who are trafficked from the North-Eastern states, Andhra Pradesh and West Bengal and brought north Indian states, face various problems like food, cultural variances and language constraints which lead to social stigma. These sufferers speak their local jargons and are not able to speak local languages Haryanvi, Punjabi or Hindi fluently. People of the destination areas easily identify victims from their speaking tone that they are an outsider and tagged as "purchased bride". All these things lead to a stigma which is known as "Paro". It is an abusive word that is given to the trafficked or bought women. These marriages are not really accepted and respected in destination areas. They are not the only victim of this kind of social stigma, their children also bear the stigma of being a son/daughter of a "Paros". Sometimes this stigma leads to the social exclusion of victims and their children.

\section{LOSS OF PROPERTY RIGHTS AND SOCIAL SUPPORT:}

Minors who are victims of early marriage are not enrolled on the local ration cards or the voter's list. This indicates that they are not recognized as permanent members of the family. The minor bride who manages to stay with the husband's family has no right on the property of the husband. Their lives became pitiable after the death of husband. These 'widows' are sold and changed hands, and if not, their families will disown them. There is no social pressure or organization to meet the basic needs of these women. If we look at the whole situation, it is obvious that their social status is nothing more than a sex toy.

\section{CONCLUSION:}

The evil of bride trafficking is destroying hundreds of women's lives every year. There are a lot of problems which are very closely associated with this problem. The problems like bonded labor, forced sex with multiple members of family, prostitution, domestic violence, culture differences issue and social stigma are some of them. Skewed sex ratio is believed to be a prominent reason for the bride trafficking in North Indian states like Haryana and Punjab but there are a lot of other reasons like poverty, dowry, illiteracy and demand for agricultural labors which are rarely discussed. Poor areas of Bihar, Jharkhand, Hyderabad and North-Eastern states, etc. are the source of bride trafficking. Haryana, Punjab, Rajasthan, Western Uttar Pradesh and some districts of Madhya Pradesh and Gujarat are the destination points of bride trafficking. The lack of government and NGOs' attention toward addressing the issue is also responsible for this problem. The law implementing agencies do not take strict action to stop the bride trafficking. The police rarely file a complaint of bride trafficking because they thought there is no such thing as bride trafficking.

\section{REFERENCES:}

[1] Assembly, U. G. (2000). Protocol to prevent, suppress and punish trafficking in persons, especially women and children, supplementing the United Nations convention against transnational organized crime. GA res, $55,25$.

[2] Editorial, (2014, November 25). The story of India's slave brides. BBC. 


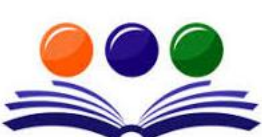

GRAND ACADEMIC PORTAL RESEARCH JOURNALS

\section{A GLOBAL JOURNAL OF SOCIAL SCIENCES}

GAP GYAN

( ISSN - 2581-5830 )

Impact Factor - SJIF - 4.998, IIFS - 4.375

Globally peer-reviewed and open access journal.

[3] Empower People. Paro or Molki: An abusive word.

[4] Hossain, S., \& Turner, S. (2001). Abduction for forced marriage-Rights and remedies in Bangladesh and Pakistan. International Family Law, 1(64), 15-24.

[5] Kara, S. (2011). Supply and demand: Human trafficking in the global economy. Harvard International Review, 33(2), 66-71.

[6] Maddox, T. (2011, March 4). Modern-day slavery: A problem that can't be ignored. CNN.

[7] Rahman, S. (2009). Paro; Ek kharidi Hui aurat. New Delhi, India: Jagori parkas

[8] Sarkar, S. (2014). Rethinking human trafficking in India: Nature, extent and identification of survivors. The Round Table, 103(5), 483-495.

[9] Srivastava, M. (2010, January 21). The new white flesh trade. India Today.

[10] United Nations Office on Drugs and Crime (UNODC). (2016). Global report on trafficking in persons,

[11]Wall Free Foundation. (2016). The Global Slavery Index (GSI) 2016. 